\title{
TUTELA JURISDICIONAL PARA ENTREGA DE COISA \\ (CPC, ART. 461-A)
}

\section{JURIDICTIONAL INJUNCTIONS FOR THING DELIVERY \\ (CPC, ART. 461-A)}

Eduardo Talamini"

\begin{abstract}
Resumo: Desde meados da década de 90 a legislação processual civil vem passando por contínuas alterações, algumas de menor realce, outras de significativa importância. Entre as incorporações, acréscimos e inovações, destacam-se as regras para tutela específica (deveres de fazer, não fazer e entrega de coisa), contidas nos Artigos 461 e 461-A do Código de Processo Civil. O presente estudo busca analisar a tutela para a entrega de coisa. Identificam-se as razões e os limites de extensão das regras do Artigo 461 (atinentes aos deveres de fazer e de não fazer) à tutela para entrega de coisa, regulada pelo Artigo 461-A.
\end{abstract}

Palavras-chave: Tutela jurisdicional. Entrega de coisa. Execução de sentença.

Abstract: From middles of the decade of 90 the civil suit legislation comes going by continuous alterations, some for minor enhance, another of significant importance. Among the incorporations, increments and innovations, they stand out the rules for it injunction specific (duties of doing, to no-do and thing delivery), contained in the Articles 461 and 461-A of the Code Civil Suit. The present study search to analyze the injunctions for thing delivery. They identify the reasons and the limits of extension of the rules of the Articles 461 (referent to the duties of doing and of no-doing) to the injuction for thing delivery, regulated by the Article 461-A.

Keywords: Juridictional injunctions. Thing delivery. Sentence execution.

\section{INTRODUÇÃO}

Na história da vigência do Código de Processo Civil de 1973, suas alterações ocupam papel destacado. Deixando de lado mudanças pontuais e isoladas presentes, aliás, desde antes do início de sua vigência (Lei 5.925/1973) - e

Mestre e Doutor pela Faculdade de Direito da Universidade de São Paulo. Professor de Direito Processual. Advogado. 
concentrando-se no conjunto de revisões iniciadas na primeira metade da década de 1990, com a Lei 8.455/1992, já se vão quatorze anos de sucessivas alterações. Vale dizer, a época das reformas corresponde a $40 \%$ do tempo de vigência do Código, com a edição de mais de vinte leis. E outras tantas estão por vir: há mais de vinte projetos em trâmite no Congresso Nacional. Até aqui, algumas delas talvez tenham sido, como já disseram alguns, meramente "cosméticas". Outras, embora sendo propriamente de conteúdo, disseram respeito a questões acessórias. Mas houve também mudanças significativas, que verdadeiramente implicaram a substituição de princípios fundamentais adotados na origem do Código. Enfim, optou-se por reformá-lo progressiva e continuamente em vez de construir um integralmente novo - com as vantagens e inconvenientes que isso traz. ${ }^{1}$

\section{A ALTERAÇÃO DE UM PRINCÍPIO GERAL}

O tema do presente texto insere-se no âmbito dessas transformações essenciais.

Originalmente, o Código consagrava a diretriz da clara separação das atividades de cognição e de execução em dois distintos processos. Não detendo o jurisdicionado um título executivo extrajudicial, cabia-lhe antes promover um processo de conhecimento destinado à formação de um título executivo judicial, para só depois, em subseqüente processo, com nova petição inicial e citação, obter a execução. A reunião de ambas as atividades na mesma relação processual, em duas fases subseqüentes, era um excepcionalidade reservada a alguns "procedimentos especiais" disciplinados no Código ou em legislação extravagante (ações possessórias, nunciação de obra nova, demarcatória, divisória, mandado de segurança etc.). Ao primeiro traço, da separação das atividades em processos distintos, associaram-se ainda outras duas características gerais: (i) a marcante tipificação dos meios destinados à produção do resultado executivo e (ii) a ausência da emissão de ordens judiciais propriamente ditas, cujo descumprimento implicasse afronta à autoridade estatal. Também no que tange a esses aspectos, as exceções residiam em "ações especiais".

Mas a separação ou unificação das atividades cognitiva e executiva em um mesmo processo, assim como os outros dois aspectos ora mencionados, deriva de razões pragmáticas, contingentes - e não ontológicas, necessárias.

Com a Lei 8.952/1994, o cenário começou a alterar-se. Mediante o conjunto de disposições reunidas no novo Art. 461 do Código, ${ }^{2}$ institui-se regime

\footnotetext{
${ }^{1}$ Resta saber se é aplicável aos diplomas legislativos o dito jocoso utilizado na construção civil, segundo o qual "reformar é tão incômodo quanto construir um novo, com a diferença de que custa mais caro".
} 
diferenciado de tutela relativa aos deveres de fazer e de não fazer. Eis os seus principais traços: ${ }^{3}$

a) consagra-se a máxima da preferência absoluta pelo resultado específico que se teria com o cumprimento do dever de fazer ou não-fazer. Apenas em última hipótese, quando isso for impossível ou houver pedido do autor, far-se-á a conversão em perdas e danos;

b) a sentença final é executada na própria relação processual em que foi proferida. Não é necessária nem cabível a instauração de um subseqüente processo de execução;

c) a sentença final, tal como a decisão que antecipa tutela, veicula também eficácia mandamental. Ou seja, o juiz tem o poder de emitir verdadeiras ordens para o cumprimento do dever de fazer ou não fazer;

d) cabe a cominação, inclusive de ofício, de multa diária ou com outra periodicidade pelo descumprimento do comando judicial. Tal multa tem caráter coercitivo, e não indenizatório ou punitivo. Destina-se a pressionar o réu ao cumprimento da ordem do juiz.

e) o juiz está ainda investido de amplos poderes para adotar inclusive medidas atípicas, não expressamente previstas, destinadas a substituir a conduta do réu no cumprimento da obrigação (medidas sub-rogatórias) ou a pressionar o próprio réu a cumprir ele mesmo a obrigação devida (medidas coercitivas);

f) previu-se especificamente o cabimento de medida urgente de antecipação de tutela, que pode ser concedida inclusive liminarmente. E - eis o detalhe mais importante - para a efetivação dessa medida podem ser utilizadas todas as providências sub-rogatórias e coercitivas utilizáveis para a execução da própria sentença final.

Não cabe aqui discutir as classificação das sentenças, para saber se é viável aludir a sentenças "mandamentais" e "executivas" como algo distinto das sentenças "condenatórias". Tenho defendido tal distinção. ${ }^{4}$ Mas aqui importa apenas destacar que mesmo doutrinadores que recusam a diferenciação reconhecem que o modelo estabelecido com o novo Art. 461 é significativamente distinto daquele

${ }^{2}$ Os dispositivos legais adiante indicados sem expressa referência a uma diploma legal pertencem ao Código de Processo Civil.

${ }^{3}$ Para o exame aprofundado de cada uma dessas características remete-se a estudo anterior (TALAMINI, 2003, passim).

${ }^{4}$ Cf. Capítulo 6 de Tutela relativa aos deveres de fazer e de não fazer (2003, p. 187-217); e Tutelas mandamental e executiva..., n. 2, (1997, p. 137-151). 
disciplinado pelo Livro II do Código (e aplicável - note-se - inclusive ao "cumprimento de sentença" condenatória ao pagamento de quantia, conforme Art. $475-\mathrm{R}){ }^{5}$

Mas até então tinha-se apenas uma exceção ao regime geral. Foi com a instituição do Art. 461-A (Lei 10.444/2002), que estendeu à tutela para a entrega de coisa as regras do Art. 461, que a diretriz geral veio a alterar-se. A partir daí a separação das atividades cognitiva e executiva em processos distintos passou a ser uma exclusividade da tutela referente ao pagamento de quantia (e, ainda assim, por pouco tempo: a Lei 11.232/2005 veio a também prever que em regra a execução da condenação por quantia certa seja feita no próprio processo em que se formou o título).

Além disso, também se tornou regra geral - excetuando-se a tutela pecuniária - a autorização para o emprego de providências executivas atípicas pelo juiz (nesse ponto, a tutela relativa a pagamento de quantia permanece alheia a essa nova regra geral: como já afirmado, nos termos do Art. 475-R, aplica-se ao "cumprimento de sentença" a disciplina do Livro II do Código, que tipifica rigidamente os meios executivos utilizáveis).

\section{AS RAZÕES PARA A EXTENSÃO DAS REGRAS DO ART. 461 À TUTELA PARA ENTREGA DE COISA}

O dever de entregar coisa fungível ou infungível envolve prestação eminentemente fungível: há a possibilidade de que terceiros se substituam ao sujeito incumbido do dever e obtenham o bem devido. Assim, poder-se-ia supor que tais deveres já receberiam tutela adequada e suficiente através da estrutura tradicional condenação (posterior à violação do direito) seguida de processo autônomo de execução.

Mas mesmo nesse campo, são inúmeras as situações que exigem proteção que vá além. Podem ser mencionadas, entre outras hipóteses:

i) os deveres contínuos e periódicos que correm o risco de sofrer repetição de violação - para os quais se justifica "condenação para o futuro" (formação do título executivo prévio ao inadimplemento - ex.: CPC, Art. 290); ${ }^{6}$

\footnotetext{
${ }^{5}$ P. ex., vejam-se as referências no interessante Ensaio sobre o cumprimento das sentenças condenatórias, de Cassio Scarpinella Bueno (2004, p. 37, n. 2).

${ }^{6}$ Sobre a regra do art. 290 como autorizadora de "condenação para o futuro", veja-se Calmon de Passos, Comentários, III, n. 149, p. 235-237. Sobre a "condenação para o futuro", vede Talamini, Tutela relativa aos deveres de fazer e de não fazer, n. 7.5, p. 225226.
} 
ii) os casos de urgência, em que a violação do dever tende a gerar, ainda que reflexamente, danos graves e de difícil reparação (ex.: obrigação de fornecimento de matéria-prima indispensável para a atividade da empresa credora) - para os quais são necessários provimentos urgentes, com eficácia executiva e (ou) mandamental, que poderão até ser emitidos antes da própria violação, a fim de operar sanções preventivas ou simultâneas. Isso já podia ser propiciado, mesmo antes da Lei 10.444/2002, pelo Art. 273 do Código de Processo Civil;

iii) as pretensões reais (ex.: reintegração de posse, ação de imissão na posse) para as quais não se justifica o emprego da condenação seguida de "execução para entrega de coisa”, sendo-lhes mais adequados pronunciamentos executivos (i.e., cuja execução dispense a instauração de novo processo). Mas isso depende do direito positivo: se a lei não atribuir tal eficácia às decisões que tutelam as pretensões reais, ela não será extraível de uma suposta "natureza das coisas";

iv) os deveres de entrega de coisa cuja realização mediante meios sub-rogatórios tende a ser extremamente dificultada se não houver a colaboração do sujeito passivo (por exemplo, para indicar onde está bem móvel) - para os quais se revela útil e razoável o emprego de provimentos mandamentais.

Uma mesma situação carente de tutela pode inserir-se em duas ou mais dessas quatro hipóteses.

Conforme apontado, para as situações descritas em "i” e "iì" já existiam em nosso sistema instrumentos de tutela adequados. Não, porém, para as indicadas sub "iii" e "iv". Nem todas as pretensões reais ("iii”, acima) eram objeto de tutela mediante pronunciamentos diretamente executivos. E não eram previstos meios coercitivos para pressionar o obrigado à entrega da coisa, a fim de que ele colaborasse com sua própria conduta.

Por isso, ainda antes da Lei 10.444, apontava-se que a incidência de regime semelhante ao do Art. 461 poderia vir a apresentar significativa utilidade para a tutela referente à entrega de coisas. ${ }^{8}$

É bem verdade que, conforme o fundamento do dever de entrega da coisa, já existiam tutelas diferenciadas, revestidas de mecanismos cuja eficiência equivale à daqueles previstos no Art. 461. Basta considerar a disciplina da reintegração de posse, da busca e apreensão, do despejo, da ação de depósito etc. Além disso, no

\footnotetext{
${ }^{7}$ Sobre o tema, v. Tutela relativa aos deveres de fazer e de não fazer, nota 6.3 (TALAMINI, 1997, p. 197-200.)

${ }^{8}$ Cf. Talamini (1997, p. 471-475, n. 20.2).
} 
procedimento dos Juizados Especiais, a multa já era aplicável à execução para entrega de coisa (Lei 9.099/95, Art. 52, V).

Todavia, não existia idêntica previsão na disciplina geral de tutela para entrega de coisa. A multa era expressamente prevista apenas para a tutela relativa a deveres de fazer e de não-fazer. Antes da reforma de 1994, prevalecia o entendimento de que a multa diária não era extensível à tutela referente à entrega de bens ou pagamento de quantia (Súmula 500 do STF: "Não cabe a ação cominatória para compelir-se o réu a cumprir obrigação de dar”). Porém, a partir da instituição das atuais normas dos Arts. 273 e 461 (pela Lei 8.952/94), não foram poucas as autorizadas vozes que passaram a afirmar que a cominação de multa, pelo menos para a efetivação da tutela antecipada, poderia ser estendida aos deveres com objeto distinto do fazer e do não-fazer. ${ }^{9}$

De iure condito, punha-se o óbice da ausência de norma autorizando o emprego do meio coercitivo patrimonial fora do campo da tutela do dever de fazer e de não-fazer. É sempre necessária a permissão no ordenamento para o emprego de um meio coercitivo. Como escreveu Chiovenda, os "meios executivos" (na ampla acepção chiovendiana) que afrontam a liberdade individual ou a propriedade, constitucionalmente asseguradas, dependem de norma expressa. (1965, v. 1, p. 288). Esse entendimento pode ser até atenuado especialmente em relação aos meios sub-rogatórios; mas não absolutamente desconsiderado, sobretudo no terreno dos meios de coerção. Há diferença essencial entre as medidas de coerção e as medidas sub-rogatórias, que repercute nos diferentes graus de exigência de tipificação de umas e outras. As medidas de sub-rogação destinamse diretamente à satisfação do provável direito antecipadamente tutelado. Em certas condições, independem de expressa previsão legislativa precisamente porque não importam sacrifício a outro bem senão àquele que já seria atingido pelo cumprimento do dever. Já a medida coercitiva implica o sacrifício de outro bem que não aquele que é objeto do dever - o que dependeria de autorização legal, quando menos genérica. Como afirma Barbosa Moreira: "as regras que autorizam o emprego de medidas coercitivas não comportam aplicação em hipóteses não

${ }^{9}$ Confiram-se, entre outros, tratando da antecipação de tutela: Bedaque, Tutela, cap. VI, n. 33, p. 365; Moniz de Aragão, Alterações..., n. 10.1, p. 243 (sustentando também a aplicação do § 5.a do Art. 461), Marinoni, A execução..., p. 162-163. Marcelo Guerra, em Execução indireta, n. 4.2.1, b.2 e b.3, p. 184 e seguintes, defendeu a extensão da multa e das medidas coercitivas atípicas à efetivação da própria tutela final relativa a deveres de qualquer natureza. V. também Wambier e Teresa Wambier, Breves comentários, Art. 461-A, p. 115, nota de rodapé 1. 
previstas”. (BONDIOLO, 2002, p. 43). E não havia na disciplina vigente antes da Lei 10.444/2002 sequer a atribuição de poderes gerais, tais como os do Art. 461, § 5.. , para o juiz efetivar a tutela para a entrega de coisa.

Daí por que era conveniente a alteração da lei, de modo a estender a multa e outros aspectos do regime do Art. 461 à tutela para entrega da coisa, no processo civil em geral. (TALAMINI, 1997).

Como afirmado acima, a entrega da coisa, em si, é atividade por excelência passível de sub-rogação. Isso em princípio poderia gerar alguma dúvida quanto à especial utilidade das técnicas coercitivas nesse campo. O princípio da economia processual, por um lado, e o do menor sacrifício, por outro, desaconselhariam o estabelecimento de meios de coerção. Mas a essa primeira conclusão devem ser acrescentadas duas ressalvas.

Primeiro, não se pode ignorar que, muitas vezes, a efetivação da tutela tendente à entrega da coisa (núcleo do dever), em princípio realizável por meios subrogatórios, pode ter sua eficácia comprometida pela inobservância, por parte do obrigado, de deveres instrumentais de colaboração (indicação de onde o bem se encontra, viabilização de acesso ao bem etc.). Os fins visados por alguns desses deveres acessórios também são perfeitamente atingíveis independentemente da vontade do devedor (assim, a negativa de acesso ao local em que o bem encontrase é superada através do arrombamento e ingresso coativo). Outros, contudo, podem assumir caráter infungível. Tome-se como exemplo o dever de indicar onde está a coisa a ser apreendida. Esses deveres instrumentais implicam a prestação de um fato ou uma abstenção de cunho acessório. Ante tais situações, Mendonça Lima chegava ao ponto de sustentar a "transformação" da obrigação de dar em obrigação de fazer, a fim de que se lhes aplicasse a tutela concernente a esta última (LIMA, 1991, v. 6, p. 651). Mas era inviável tal solução de lege lata. Tais deveres instrumentais de fazer e de não-fazer têm natureza processual. Recaem, em última instância, no dever de colaborar com o funcionamento da justiça e não praticar atos que atentem contra sua dignidade. $O$ desrespeito a deveres de fazer e de não-fazer instrumentais, de cunho processual, no curso da efetivação da tutela referente a pagamento de soma ou entrega de coisa, não tinha o condão de subverter ou transformar o regime dessa tutela. Portanto, a solução não havia como ser obtida por esse artifício da "transformação" - que, aliás, foi rejeitado pela jurisprudência. ${ }^{10}$ Era necessário mudar a lei. As mesmas razões que ampararam a instauração do sistema especial do Art. 461 justificavam alteração

${ }^{10}$ 2. TACivSP, AI 678.544-00/1, v.u., rel. J. Antonio Rigolin, j. 13.02.2001, em RT 789/ 303; TJRN, AI 02.000306-4, v.u., rel. Des. R. Godeiro, j. 14.06.2002, em RT 803/383. 
legislativa que possibilitasse a adoção de semelhantes mecanismos nos casos de entrega de coisa que dependesse de colaboração ativa do réu. ${ }^{11}$

Além disso, a multa pode ser instrumento de grande eficiência nas situações urgentes enfrentadas pela antecipação da tutela para entrega da coisa. A necessidade de pronta obtenção do bem, para afastar dano grave e de difícil reparação, muitas vezes, não será suprida pelo mero uso de meios sub-rogatórios (busca e apreensão, desocupação forçada). Nessas hipóteses, e sem prejuízo da simultânea autorização de atos sub-rogatórios, a ordem direta ao réu para que entregue ou desocupe o bem é providência adequada - e terá sua autoridade e eficiência reforçadas, se puder acompanhar-se da cominação de multa para o caso de desatendimento.

\section{O MODELO INSTITUÍDO PELO ART. 461-A}

Por tais razões, foi conveniente a mudança legislativa que estendeu a vários dos aspectos do regime ex Art. 461 à tutela para a entrega de coisa (Lei 10.444/ 2002).

E é dentro do panorama apresentado no item anterior que devem ser interpretadas as regras sobre tutela para entrega de coisa. ${ }^{12}$

\subsection{Execução da sentença no próprio processo em que proferida}

Ficou estabelecida a eficácia executiva da sentença que impõe o cumprimento de dever de entrega de coisa. ${ }^{13}$ No âmbito das pretensões com tal objeto, eliminouse também o binômio condenação-execução.

No processo a que se refere o Art. 461-A, tal como o do Art. 461, desenvolvese inicialmente atividade jurisdicional cognitiva. É processo comum de conhecimento, que se submeterá ao procedimento ordinário ou sumário, conforme o caso.

${ }^{11} \mathrm{~A}$ inobservância do dever de indicar onde se encontram os bens sujeitos à execução já era passível de multa de até $20 \%$ do "valor atualizado do débito em execução" (Arts. 600, IV, e 601). À parte a dúvida quanto à possibilidade de estender tal sanção para além do processo executivo (ainda que o dever, em si, a ele não se limite), é de se constatar sua tênue eficácia.

${ }^{12}$ Em linhas gerais, o exame que segue já foi apresentado em Tutela relativa aos deveres de fazer e de não fazer - e sua extensão aos deveres de entrega de coisa (CPC, Arts. 461 e 461-A; CDC, Art. 84), n. 20.2 (TALAMINI, 1997, p. 469-475).

${ }^{13}$ Os provimentos de antecipação de tutela, mesmo no regime anterior, já se revestiam dessa eficácia (v. item 3, acima). 
Mas, depois que se torna eficaz a sentença que acolhe o pedido e determina a entrega da coisa - também como no processo do Art. 461 -, não há uma petição inicial de ação executiva nem uma nova citação do réu. No próprio processo em que acolhe o pedido, assim que eficaz a sentença, o juiz adota as providências para que ela seja efetivada: não havendo a entrega do bem pelo réu no prazo fixado, expede-se em favor do autor mandado de busca e apreensão ou de imissão na posse, conforme se trate de coisa móvel ou imóvel (Art. 461-A, caput e $§ 2$. a ).

O caráter executivo da sentença ex Art. 461-A faz com que não caibam embargos à sua execução. É que tal execução ocorre no próprio processo em que foi proferida a sentença, não se submetendo às regras do Livro II do Código.

Conseqüentemente, não cabem tampouco embargos de retenção por benfeitorias (que nada mais são do que embargos à execução qualificados pela matéria sobre a qual versam). Cumpre ao réu fazer valer o direito de retenção por benfeitorias na contestação, durante a fase cognitiva do processo - sob pena de preclusão. ${ }^{14}$

Por outro lado, não fica obstado o cabimento de embargos de terceiro, que não consistem em processo incidental à execução do Livro II, mas instrumento de defesa da posse (ou dos direitos advindos de garantia real) contra atos ofensivos praticados por órgãos jurisdicionais em qualquer tipo de processo de que o possuidor (ou detentor de garantia real) em regra não faça parte.

Como já se observou acima, em certa perspectiva, o modelo que constituía exceção em nosso sistema começa a assumir caráter de norma geral: cognição e execução reúnem-se em um mesmo processo.

\subsection{As pretensões tuteladas pelo Art. 461-A}

A inovação é de extrema relevância especialmente para determinadas pretensões reais que se ressentiam de um modelo de tutela mais adequado (imissão de posse, reivindicação, reintegração de posse contra esbulho com mais de ano e dia etc.). Afinal, era minoritário o entendimento de que as pretensões reais à entrega

${ }^{14}$ Reitere-se que esse é um traço típico da sentença dita "executiva", pacificamente aceito, p. ex., no âmbito das possessórias (v. RSTJ75/357, com indicação de precedentes; Talamini, Embargos do executado, n. 8, p. 102; Malachini, Comentários, n. 3 ao Art. 744, p. 575-576). Tratando já do Art. 461-A: Talamini, Tutela relativa aos deveres de fazer, n. 20.2, p. 469; Abelha Rodrigues, $A$ nova reforma, cap. III, n. 5, p. 238; Juvêncio V. Viana, Alterações, n. 9, p. 69. N. Rodrigues Netto cogita ainda do cabimento de reconvenção para a cobrança de indenização pelas benfeitorias (Notas..., n. 3.2, p. 210). 
de coisa inerentemente se revestiriam de força executiva, a despeito de não haver expressa previsão legal. Sempre prevaleceu a orientação de que, independentemente do fundamento real ou pessoal da pretensão à entrega de coisa, seria aplicável, em regra, o processo de execução do Art. 621 e seguintes, a ser amparado em título judicial ou extrajudicial. As ações executivas para entrega de coisa apenas tinham cabimento quando expressamente previstas (ex., despejo, reintegração de posse em casos de turbação de menos de ano e dia, demarcatória, divisória etc.). Agora, a questão está superada: a via geral de tutela em relação aos deveres de entrega de coisa passou a ser a prevista no Art. 461-A.

Mas as normas previstas nesse novo artigo não são importantes apenas para as pretensões reais. São também bastante úteis para pretensões meramente obrigacionais (p. ex., inquilino contra o locador, para assumir posse de bem locado mas não entregue).

Enfim, o regime instituído pela conjugação do Art. 461-A com o Art. 461 vale para todos os deveres de entrega de coisa (cabendo apenas examinar as relações entre a nova via geral e as vias especiais de tutela para entrega de coisa v. item 4.9, adiante). Em síntese: o dever pode ter fundamento real ou obrigacional; a coisa pode ser móvel ou imóvel, fungível ou infungível.

\subsection{A individualização de "coisa determinada pelo gênero e quantidade"}

No que tange à "coisa determinada pelo gênero e quantidade" procurou-se instituir sistema simplificado para sua individualização, que não diverge substancialmente do já previsto para a execução para entrega de coisa: "o credor a individualizará na petição inicial, se lhe couber a escolha; cabendo ao devedor escolher, este a entregará individualizada, no prazo fixado pelo juiz" (Art. 461-A, $\S 22^{\circ} .{ }^{15}$

A definição de a quem cabe a individualização, se ao autor ou ao réu, provém do direito material. A regra geral é a de que, não havendo pactuação em outro sentido, a escolha caiba ao devedor (C. Civ., Art. 244). Mas em qualquer caso, tal escolha é impugnável pelo adversário e controlável pelo juiz, pois o devedor não pode dar coisa de qualidade pior nem está obrigado a entregar bem de qualidade melhor do que a pactuada (C. Civ., Art. 244, parte final).

O juiz zelará inclusive para que se respeite o eventual direito de individualização do réu: se o autor estiver indicando o bem, a despeito de a

${ }^{15}$ Sobre a individualização do bem no processo do Art. 461-A, ver Tutela específica, nota 3 (BONDIOLI, 2002, p. 175-176). 
escolha não lhe caber, o juiz reputará sem efeito tal individualização, determinando apenas a citação para que o réu entregue a coisa que escolher. No processo de execução do Livro II, há quem sustente que, nesse caso, o juiz deveria simplesmente indeferir a citação (MOREIRA, 2002, p. 202). A solução ora alvitrada, contudo, além de tomar em conta a economia processual, aproveita analogicamente a regra do Art. 288, parágrafo único (que trata de obrigação alternativa - figura distinta da aqui examinada).

Por outro lado, se, cabendo a individualização ao autor, ele deixa de fazê-la na inicial, preclui-lhe tal faculdade. Isso implica renúncia à escolha e sua transferência ao réu. Idêntica solução é aplicável ao caso em que o réu deixa de promover, no prazo fixado pelo juiz, a individualização que lhe cabe.

Feita a escolha, a parte adversária tem o direito de impugná-la. O Art. 461-A não estabeleceu prazo para essa impugnação. Assim, cumpre definir se, à falta da fixação de outro específico pelo juiz, será aplicável o prazo geral de cinco dias (Art. 185) ou se aplicará subsidiariamente a regra do Art. 630 que prevê prazo de 48 horas para a formulação dessa impugnação no processo de execução para entrega de coisa. Mais ainda, no que tange ao réu, há uma terceira possível solução: como o autor formulará a individualização na inicial, é razoável que o réu contra ela se insurja na própria contestação, que, regra geral, deve ser apresentada no prazo de quinze dias da juntada do comprovante de citação aos autos. Essa última solução, específica para o réu, é a mais razoável. Considere-se que aqui há uma diferença substancial em relação ao processo de execução do Art. 621 e seguintes. Lá não se exercita defesa por meio de contestação, razão por que se fez necessária a previsão de um incidente específico para impugnar a individualização, com prazo próprio. Já no processo comum de conhecimento (em que se insere a tutela do Art. 461-A), como há exercício de defesa mediante contestação, é dentro dessa peça que o réu deve impugnar a escolha feita pelo autor (CPC, Art. 300). Por outro lado, se não se aplica o prazo de 48h para o réu, também não se deve aplicá-lo ao autor. Esse deverá ser intimado para se manifestar sobre a escolha feita pelo réu no prazo que o juiz fixar. Afinal, se é o juiz quem define concretamente o prazo para a individualização pelo réu (Art. 461-A, $\S 1^{\circ}$ ), deve também definir in concreto o prazo para o autor manifestar-se sobre ela. Não havendo expressa definição de prazo pelo juiz, aplica-se a regra do Art. 185.

As decisões do juiz sobre o tema serão obviamente recorríveis. Normalmente se tratarão de decisões interlocutórias, portanto, passíveis de agravo. Quando a matéria for resolvida na própria sentença, deverá ser objeto da apelação.

$\mathrm{Na}$ execução do Livro II do Código, o momento da individualização pelo exeqüente, ao menos em tese, está bem próximo do momento da apreensão 
executiva do bem. No processo do Art. 461-A, porém, as coisas se passam de modo diferente. Se a escolha do autor for feita na inicial, como determina o $\S 1^{\circ}$ do Art. 461-A, há a perspectiva de que apenas muito depois se venha a ter a atuação propriamente executiva, de apreensão do bem. Afinal, antes disso haverá contestação e todo o desenvolvimento de instrução inerente a processo comum de conhecimento. Mais ainda: a apelação em regra se reveste de duplo efeito (Art. 520). Assim, e tirando-se a hipótese em que houver liminarmente antecipação de tutela, haverá um lapso temporal longo entre a individualização pelo autor e a efetiva entrega ou apreensão do bem. Isso pode implicar evidentes prejuízos ao autor. Pense-se na hipótese de os bens já individualizados pelo autor virem a perecer, muito embora o réu continue titularizando outros do mesmo gênero em quantidade suficiente para responder pela obrigação. Nessa hipótese, não parece razoável impor-se ao autor pura e simplesmente a conversão em perdas e danos sob o argumento de que os bens individualizados pereceram. Cabe dar-lhe a alternativa de uma nova individualização. Apenas assim se estará respeitando a imposição de máxima preferência pelo resultado específico que se teria com o cumprimento espontâneo e pontual da obrigação (Art. 461, $1^{\circ}$, aplicável por força do Art. 461-A, $\S 3^{\circ}$ - e que, de resto, é expressão da garantia constitucional da tutela jurisdicional plena e adequada). ${ }^{16}$

Já quando a individualização couber ao réu, em princípio não deve ocorrer problema semelhante. O Art. 461-A, $\S 1^{\circ}$, prevê que o juiz fixará o momento em que o réu deve exercer tal escolha - e obviamente o juiz deverá abrir ao réu a oportunidade de individualização em momento imediatamente anterior ao do cumprimento do mandado de entrega ou apreensão do bem, fundado em sentença de procedência ou em decisão concessiva de tutela antecipada.

\subsection{O campo de incidência da execução para entrega de coisa (CPC, Art. 621 e seguintes)}

A execução para entrega de coisa prevista no Livro II do Código ficou restrita precipuamente aos títulos executivos extrajudiciais (cf. a redação dos Arts. 621, 624 e 627, dada pela Lei 10.444/2002).

${ }^{16}$ Há doutrinadores que nem sequer consideram que o $\S 1^{\circ}$ do Art. 461-A possa estar propriamente se referindo à inicial da ação. Assim, Dinamarco: "uma interpretação razoável do novo dispositivo deve concluir que a escolha, a ser feita pelo autor, virá na petição com que ele pedir as medidas inerentes ao Art. 461-A c/c Art. 461" (2002, p. 249, n. 176) - no que é endossado por Tucci (2002, p. 83, n. 3 ao Art. 461-A). 
Também aqui, a exemplo do que já vinha ocorrendo em relação aos deveres de fazer e de não fazer, permanecem existindo determinados títulos judiciais cuja efetivação dar-se-á pelo processo executivo do Livro II. Recapitula-se a seguir, com as devidas adaptações, o já exposto em textos anteriores, que tratavam do tema à luz do Art. $461 .{ }^{17}$

Permanece havendo hipóteses de "execução para entrega de coisa" embasada em título judicial. A sentença arbitral (Art. $475 \mathrm{~N}, \mathrm{IV})$ e a sentença estrangeira homologada pelo Superior Tribunal de Justiça (Art. $475 \mathrm{~N}, \mathrm{VI}$ ) podem veicular a imposição da observância de deveres dessa natureza - e continuam ensejando o processo do Art. 621 e seguintes. ${ }^{18}$

O mesmo se diga acerca da sentença homologatória de transação ou conciliação (Art. 475N, III) que envolva dever de entrega de bem, mas que ocorra em processo que não tinha por objeto a tutela ex Art. 461-A. Isso é concebível em duas hipóteses: a) não há nenhum processo em curso, e as partes instauram procedimento judicial exclusivamente destinado a obter a homologação do juiz, nos termos do art. 57 da Lei 9.099/95 e do Art. 475-N do Código de Processo Civil; b) a transação prevendo entrega de coisa é alcançada dentro de um processo em que se pretendia forma de tutela alheia ao sistema dos Arts. 461 e 461-A (p. ex., uma ação ao pagamento de quantia ou uma ação meramente declaratória). ${ }^{19}$ Nesses casos, a sentença homologatória apenas dará ensejo ao processo de execução do Art. 621 e seguintes. Já quando a conciliação ou transação vier a ser homologada dentro do próprio processo em que se buscava a tutela ex Art. 461 ou ex Art. 461A, a sentença homologatória será dotada dos mesmos efeitos que teria a decisão de procedência do pedido - dispensando-se, para sua efetivação, subseqüente processo executivo.

${ }^{17}$ Ver Tutela relativa aos deveres de fazer e de não fazer - e sua extensão aos deveres de entrega de coisa (CPC, Arts. 461 e 461-A; CDC, Art. 84) (TALAMINI, 2003, p. 424425 , n. 18.3) e Tutelas mandamental e executiva lato sensu e a antecipação ex vi do Art. 461, \& 3., do CPC (TALAMINI, 1997, p. 168-169).

${ }^{18}$ Ressalva (parcial) feita à possibilidade de emissão, no procedimento arbitral, de pronunciamentos dotados das eficácias previstas no Art. 461-A - nos limites e sob as condições apontados em Talamini (2003, p. 459).

${ }^{19}$ A sentença homologatória de transação que verse questão não posta em juízo sempre formou título executivo judicial (ver WAMBIER; ALMEIDA; TALAMINI, 2004, v. 2, p. 5-7-59). Agora isso está novamente explicitado em lei (Art. 475N, III, conforme redação dada pela Lei 11.232/2005, que reproduziu a disposição do Art. 584, III, na redação dada pela Lei 10.358/2001). 
Em síntese, depois da reforma do Código, as sentenças proferidas em processos judiciais impondo entrega de coisa deixaram de ser executadas nos termos do Livro II, aplicando-se-lhe o regramento do Art. 461-A c/c Art. 461. As outras hipóteses de títulos judiciais, quando tiverem por objeto entrega de coisa, em princípio serão executados conforme as normas do Livro II do Código.

Note-se apenas que as sentenças determinando entrega de coisa aperfeiçoadas antes da instituição do Art. 461-A continuam a funcionar apenas como título autorizador da execução com base no Art. 621 e seguintes. Vale dizer: têm a eficácia condenatória tradicional, e não direta força executiva. Isso porque a eficácia da sentença é regulada pela lei vigente no momento da formação do pronunciamento.

\section{5 $\mathrm{O}$ interesse de agir pela via do Art. 461-A quando já se tem titulo executivo}

É igualmente aplicável outro entendimento que já tive oportunidade de defender tratando do Art. 461: o detentor de título executivo para entrega de coisa tem interesse de agir para optar pelo ajuizamento da ação conhecimento para buscar a obtenção da tutela ex Art. 461-A. (TALAMINI, 2003, p. 425-426; 1997, p. 169-170).

Tradicionamente, prevalece no Brasil o entendimento de que aquele que já possui título executivo extrajudicial não tem interesse de agir através de demanda condenatória: a sentença condenatória não lhe seria de nenhuma especial utilidade, apenas servindo para dar-lhe aquilo que ele já tem - ou seja, um título executivo. ${ }^{20}$

Agora, no que tange às previsões especiais de tutela específica dos Art. $461 \mathrm{e}$ 461-A, esse entendimento não pode ser adotado. Afinal, estabeleceu-se mecanismo muito mais completo e eficiente de tutelas do que o previsto no regime de "execução de obrigações de fazer e não fazer" e de "execução para entrega de coisa", no Livro II do Código. O suposto credor de "obrigação de fazer e não fazer" ou de "obrigação de entrega de coisa" - mesmo quando munido de título executivo - tem a faculdade de optar por um ou outro caminho. A demanda de conhecimento com base no Art. 461 pode ser-lhe mais útil - estando presente, assim, o interesse de agir.

${ }^{20}$ Vede, entre outros: Moniz de Aragão, Comentários ao CPC (ARAGÃO, 1992, v. 2, p. 574, n. 527); Direito processual civil brasileiro (GRECO FILHO, 1995, v. 1, p. 82-83, n. 14.2). Na Itália, desde Chiovenda, estabeleceu-se orientação no sentido oposto (CHIOVENDA, 1965, v. 1, p. 308, n. 88). 
Caso opte pelo direto ajuizamento de execução, não terá de discutir o mérito de sua pretensão: isso apenas ocorrerá se houver embargos. Mas, de outra parte, disporá de forma mais tênue de tutela. Em suma, caso não haja cumprimento direto pelo próprio devedor, tudo se transformará em simples execução monetária.

Já se a parte escolher a via do Art. 461 ou do Art. 461-A, nada impede que se ponha em discussão o mérito de sua pretensão. Afinal, haverá processo de cognição plena e exauriente, em que o “título executivo” não passará de elemento instrutório. Também, e eventualmente, pode até não ser concedida antecipadamente a tutela. Todavia, caso a parte consiga a antecipação ou obtenha depois sentença favorável, disporá de mecanismo muito mais célere e completo para a satisfação de seu direito.

\subsection{A extensão das regras do Art. 461 à tutela para entrega de coisa}

Além de atribuir força executiva à sentença que determina a entrega de coisa, o novo Art. 461-A prevê a aplicação subsidiária das regras do Art. 461 à tutela para entrega de coisa (Art. 461-A, § $3^{\circ}$ ). Assim, estendem-se à tutela ex Art. 461A: a eficácia mandamental, a possibilidade de cominação de multa periódicas e o emprego de "medidas de apoio" coercitivas e sub-rogatórias atípicas.

\subsection{Segue: a aplicação das medidas do $\S 5^{\circ}$ do Art. 461. A medida atípica de intervenção judicial}

A imissão na posse e a busca e apreensão, a que alude o $\S 2^{\circ}$ do Art. 461-A, são providências sub-rogatórias flexíveis que podem assumir conformação ampla. Como escreve Araújo Cintra, a imissão na posse de imóvel e a busca e apreensão da coisa móvel são "os meios executivos adequados, por excelência, para assegurar a satisfação específica da obrigação de entregar coisa”. (CINTRA, 2003, v. 4, p. 296). Desse modo, no mais das vezes nem mesmo parece que será necessário o emprego de outras medidas sub-rogatórias amparadas no $\S 5^{\circ}$ do Art. 461. Todavia, surgindo concretamente tal necessidade, as medidas ex Art. 461, § $5^{\circ}$, deverão ser adotadas no mesmo processo (art. 461-A, § $3^{\circ}$, c/c Art. 461, § 5º. Para ilustrar o que se vem de dizer, considerem-se algumas das medidas sub-rogatórias que podem ser deferidas com base no Art. 461, § 5०:

- a remoção de pessoas e coisas e a requisição de força policial, a que alude o $\S 5^{\circ}$, são providências que já estariam de qualquer modo abrangidas pela determinação de emprego da busca e apreensão ou da imissão na posse. Afinal, a imissão na posse de imóvel pode exigir a remoção de pessoas e coisas e o emprego de força policial. A busca e apreensão de 
coisa móvel também implica a remoção do bem, além de eventualmente reclamar o concurso de força policial;

- o desfazimento de obras e o impedimento de atividade nociva, que também são mencionados a título exemplificativo no $\S 5^{\circ}$, podem vir a ser de grande serventia para a tutela de entrega de coisa. Ambas as medidas estão pressupostas na sanção restituitória destinada a propiciar que o bem seja entregue ao autor no exato estado em que se deveria encontrar se não tivesse havido violação do direito nem a conseqüente necessidade de intervenção judicial. Nessa perspectiva, já seriam ínsitas à nova tutela ex Art. 461-A. De qualquer modo, a expressa previsão de que são aplicáveis as medidas ex Art. 461, $\S 5^{\circ}$, presta-se a afastar qualquer dúvida a respeito;

- a intervenção judicial é medida atípica que também pode vir a ser adotada com base no Art. 461, $\S 55^{\circ} .^{21} \mathrm{O}$ tema merece um breve destaque.

Pense-se em casos em que o bem imóvel está ocupado por uma estrutura organizacional do réu com amplitude e complexidade tais que não é possível sua simples entrega imediata: é preciso retirar equipamentos de difícil desmonte e remoção ou matérias primas que envolvem riscos, remanejar pessoal que trabalha nessas instalações etc. Em tais casos, o prazo para a entrega voluntária do bem (Art. 461-A, $\S 1^{\circ}$ ) precisará obviamente ser amplo. Não é discricionária a determinação do prazo para cumprimento. O lapso de tempo concedido ao réu não poderá ser curto em demasia, de modo que o impeça de cumprir a ordem tempestivamente, ainda que queira; nem longo a ponto de ser inócua a tutela que se concedeu ao autor. As circunstâncias concretas terão de ser consideradas. No entanto, há o risco de que o réu se aproveite amplitude do prazo que lhe é concedido para apenas ganhar tempo, não cumprindo o mandado de entrega.

Em um caso como esse, seria razoável que o juiz incumbisse alguém de fiscalizar a atuação do réu, atribuindo a tal auxiliar do juízo poderes suficientes para que pudesse verificar se o réu está efetivamente adotando medidas para a desocupação do imóvel. Não é de descartar que, uma vez constatado que o réu não está tomando tais providências, o juiz nomeie um interventor apto a diretamente interferir na administração da estrutura interna do réu de modo a que a ocupação ocorra. Trata-se de medida drástica e excepcional, mas que pode ser imprescindível à prestação adequada da tutela jurisdicional. Sobre o tema, remete-se ao texto indicado na nota 28 , acima.

${ }^{21}$ Sobre o tema, v. Talamini, (2003, p. 275-283, n. 10.4). 


\subsection{Segue: a eficácia mandamental e o emprego de meios coercitivos: limites}

Como já se indicou, também a eficácia mandamental dos provimentos e o emprego de medidas coercitivas (multa ou providências atípicas) estendem-se à tutela para entrega de coisa, por força do Art. 461-A, § $3^{\circ}$. Mas não parece que tais aspectos da atual tutela ex Art. 461, diferentemente da eficácia executiva, possam ser usados generalizadamente, em todo e qualquer caso, na tutela para entrega de coisa. Cabe seu emprego seletivo.

Afinal, quando for razoavelmente simples e rápida a busca e apreensão da coisa móvel ou a imissão do autor na posse do imóvel, não se justifica a imposição de medidas coercitivas ou o efetivo emprego da eficácia mandamental. A eficácia mandamental estará necessariamente presente nos provimentos ex Art. 461-A (§ $3^{\circ}$ ), mas não será necessariamente concretizada em efeitos. Lembre-se que a coexistência de eficácias em um mesmo pronunciamento não implica que todos os respectivos efeitos venham a ser necessariamente produzidos. A eficácia consiste na potencialidade, aptidão, de produção de efeitos. Desse modo, é possível que, muito embora a decisão seja apta a produzir dados efeitos, tal não se faça necessário. As eficácias mandamental e executiva estarão presentes no provimento antecipatório ou final ex Art. 461. No entanto, o efetivo emprego de cada uma dessas eficácias - a transformação da eficácia em efeitos - dependerá das circunstâncias concretas.

Os próprios termos do Art. 461-A indicam a ordem a ser normalmente seguida (ressalvadas as particularidades a seguir indicadas). Primeiro, concede-se prazo para entregar. Se a entrega voluntária não ocorre, promove-se, sempre que possível, a busca e apreensão ou a imissão na posse.

O emprego concreto de ordem acompanhada de multa ou mecanismos coercitivos atípicos deve ser reservado basicamente às situações antes cogitadas:

a) na antecipação de tutela, quando houver extrema urgência na pronta obtenção do bem;

b) em relação aos deveres instrumentais, como o de indicar onde a coisa móvel está, permitir-lhe acesso, fornecer informações necessárias para sua eventual desinstalação (deveres de fazer, na essência);

c) nos casos em que a desocupação do bem imóvel ou a entrega do bem móvel reveste-se de peculiaridades tais que a tornam complexa a ponto de ser difícil realizá-la sem a ajuda do réu. Serve também aqui como exemplo aquele pouco acima utilizado ao se tratar da intervenção judicial.

Além disso, a regra do $\S 3 .^{\underline{a}}$ do Art. 461-A também é bastante útil na medida 
em que elimina possíveis impasses na escolha dos meios, na tutela de situações cuja qualificação como dever de entregar ou de fazer é bastante difícil. Afinal, nem sempre é clara a distinção entre o dever de fazer e o de dar. Há casos em que em um mesmo dever reúnem-se a imposição de uma atividade (que não se confunde com a simples entrega de coisa) e a imposição de entrega ou transferência patrimonial de bem corpóreo. Incluem-se aí (a) os deveres que têm por objeto uma prestação "mista”, em que o fazer está indissociavelmente relacionado com a entrega de bens e (b) as hipóteses de "complexidade da obrigação simples”. Esse último termo é utilizado pela doutrina civilista para se referir à série de "deveres acessórios de conduta" eventualmente contidos mesmo na relação obrigacional que não é "complexa” (ou seja, que não é constituída por várias obrigações, mas sim por uma única obrigação principal) (VARELA, 1977, v. 1, p. 62-64). ${ }^{22}$ A noção é extensível aos deveres não obrigacionais. Exemplifique-se com o dever de entrega de equipamentos através de uma forma especial e particularizada de transporte, que seria propiciado pelo próprio vendedor. Antes da regra do Art. 461-A, seria tormentoso definir o cabimento da tutela do Art. 461 nesse caso: discutir-se-ia qual a obrigação preponderante, a entrega dos bens ou o seu transporte (obrigação de fazer). Agora, não há dúvidas, aplicam-se as regras do Art. 461, seja diretamente, seja pela determinação do Art. 461-A, § $3^{\underline{a}}$.

Quanto aos parâmetros de cabimento, critérios para fixação e alteração de valor, periodicidade, termo inicial e final, exigibilidade, modo de execução e os demais aspectos do regime jurídica da multa processual, remete-se ao quanto exposto em oportunidade anterior. ${ }^{23}$

\subsection{A relação entre a via geral do Art. 461-A e as vias especiais de tutela para a entrega de coisa}

Por fim, cabem brevíssimas considerações sobre a relação entre a nova via geral de tutela para entrega de coisa e as vias especiais já antes existentes para esse fim (reintegração de posse, despejo, busca e apreensão, depósito, apreensão de títulos etc.). ${ }^{24}$

${ }^{22}$ Veja-se também Orlando Gomes - aludindo a "deveres secundários"- (1980, p. 157162, cap. 13). Sobre as repercussões processuais do tema, v. Talamini (2003, p. 132-134, n. 4.3).

${ }^{23}$ Tutela relativa aos deveres de fazer e de não fzaer..., cap. 9 (TALAMINI, 2003).

${ }^{24}$ São integralmente aplicáveis as considerações feitas no capítulo 19 do já referido Tutela relativa aos deveres de fazer e de não fazer... 
Normalmente, a parte que poderia empregar a via especial não fica impedida de se valer da via do Art. 461-A. A previsão de instrumento de tutela geral, como é o caso do Art. 461 e do Art. 461-A, funciona como norma de encerramento do sistema, destinada a proteger situações não abarcadas pelas providências típicas. Dá cumprimento à imposição constitucional de universalidade da tutela jurisdicional, ao assegurar que todas as situações carentes de proteção sejam efetivamente protegidas, e não só aquelas lembradas ou imaginadas pelo legislador. Daí que a previsão de medidas típicas para certas situações não implica, por si só, a vedação do emprego de providências similares embasadas no "poder geral", em casos em que não estão presentes os requisitos específicos da via típica. É que esta, no mais das vezes, representa apenas especial preocupação com uma hipótese de maior ocorrência prática ou mais relevante..$^{25}$ Deve, portanto, ser compreendida como um reforço ao sistema geral - e não um óbice à universalidade da tutela adequada.

Portanto, e em regra, a parte, em vez de lançar mão da via especial de tutela para entrega de coisa, pode recorrer ao instrumento geral ex vi do Art. 461-A. Por exemplo, o possuidor do imóvel, mesmo tendo sofrido o esbulho há menos de ano e dia, pode optar por ação comum de conhecimento em que pleiteará a tutela do Art. 461-A, em vez de promover a ação de reintegração de posse. Ele tem interesse processual para essa opção porque pode preferir não limitar a discussão e o pronunciamento judicial à questão possessória, buscando desde logo o reconhecimento do domínio - o que lhe está vedado no âmbito das ações possessórias típicas (Art. 923).

Porém, há casos excepcionalíssimos em que a previsão de via de tutela típica não se faz como reforço ao sistema geral - e, sim, para disciplinar a exceção a uma regra geral de proibição do emprego daquela medida. Mas não se trata de algo que ocorra com freqüência no âmbito da tutela para entrega de coisa. Nessa seara, talvez um dos poucos casos que não autorizem o emprego da via geral em lugar da especial seja o da ação de despejo (Lei 8.245/91, Art. 59 e seguintes). Considera-se que a tipificação dessa via para a retomada de imóveis locados representa a definição de um caminho único: o próprio legislador já teria sopesado os valores envolvidos, de modo a compatibilizar a proteção ao locador sem o excessivo sacrifício do locatário.

${ }^{25}$ Ao menos essa é a razão do surgimento da tutela típica - que, não raramente, acaba "sobrevivendo" no ordenamento, até em sucessivos diplomas, mesmo depois de já não existirem os motivos de sua instauração. 
Por outro lado, a diretriz geral é também a de que as regras do Art. 461-A (e, por conseqüência, as do Art. 461) são subsidiariamente aplicáveis às vias típicas de tutela para a entrega de coisa. Se uma "ação especial” foi criada para conferir a determinadas situações proteção mais completa do que a atribuída à generalidade dos casos, sua disciplina diferenciada, por si só, não pode constituir empecilho à incidência das regras gerais, quando estas são alteradas e passam a propiciar mecanismos de tutela mais eficientes.

Por exemplo, a multa diária passa a poder ser utilizada inclusive ex officio em "ações especiais" que não a contemplavam (ou que a condicionavam a requerimento da parte). Obviamente, deverão ser observados os limites há pouco apontados (item 4.8 do artigo).

Aliás, em ações como a de busca e apreensão de bens alienados fiduciariamente (Art. $3^{\circ}$ do Dec.lei 911/69), de depósito (CPC, Arts. 901-906) e de protesto e apreensão de títulos (Arts. 882-887), a possibilidade de cominação de multa de incidência periódica ou de emprego de outras medidas coercitivas atípicas assume ainda maior importância. É que em tese se prevê para tais vias de tutela o cabimento de prisão civil. Ocorre que tais previsões são incompatíveis com o sistema de garantias constitucionais, na dimensão que ora lhe conferem os tratados internacionais sobre direitos humanos ratificados pelo Brasil: apenas a dívida alimentícia autoriza atualmente o emprego da prisão civil. ${ }^{26} \mathrm{~A}$ possibilidade de serem usadas outras espécies de medidas coercitivas presta-se a conferir eficiência a essas vias especiais de tutela (diminuindo a força do argumento freqüentemente empregado por aqueles que pretendem sustentar que continua cabendo prisão civil nesses casos).

Com a instituição do Art. 461-A ficou superada a discussão sobre ser a exibição de documentos e coisas um dever de fazer ou de entrega de coisa, para os fins de aplicação das medidas ex Art. 461. Ainda que se reputando tratar de dever de entrega de coisa - que parece o mais correto -, é agora possível empregar, na ação ou incidente de exibição, a multa e medidas coercitivas ou sub-rogatórias atípicas (Art. 461-A, § $3^{\circ}$, c/c Art. 461, §§ $4^{\circ}$ e $5^{\circ}$ ).

O Art. 461-A é também aplicável subsidiariamente à ação de reintegração de posse. É bem verdade que as eficácias executiva e mandamental já estão presentes nas sentenças das ações possessórias, mesmo quando essas são ajuizadas depois de passado o prazo de "ano e dia". ${ }^{27}$ Nesse aspecto, poderia parecer que a disciplina

${ }^{26}$ Vede: Prisão civil e penal e 'execução indireta' (a garantia do Art. 5., LXVII, da Constituição Federal (TALAMINI, p. 150-153, n. 5) e Ainda sobre a prisão como "execução indireta", (TALAMINI, 2001, p. 281-282, n. 1).

${ }^{27}$ Sobre a presença de tais eficácias nas ações possessórias, inclusive nas de "posse velha", 
dos Arts. 461 e 461-A não teria nada com que contribuir. Porém, há espaço para a aplicação subsidiária desses dispositivos, no que diz respeito à multa na manutenção e na reintegração de posse. Enquanto no interdito proibitório a multa é providência que o juiz deverá adotar de ofício uma vez pleiteada a tutela (Art. 932), na manutenção e na reintegração, nos termos do Art. 921, II, a multa dependeria de pedido "cumulado" do autor e só serviria para inibir "nova turbação

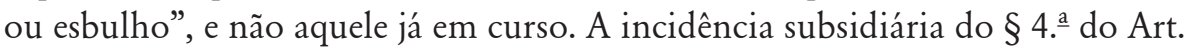
461 presta-se a permitir que o próprio juiz, a fim de reforçar a autoridade de seu comando, comine de ofício multa diária pela continuidade do esbulho ou turbação em curso. Além disso, na ação ajuizada depois de decorrido o prazo de "ano e dia" da turbação ou esbulho, fica obstada a concessão de mandado liminar de manutenção ou reintegração mediante a mera prova sumária da continuidade da posse e de sua turbação (Art. 924 c/c Art. 928). Nada obsta, todavia, que, uma vez demonstrados o fundamento relevante da demanda (prova sumária da posse) e o perigo de dano de difícil reparação, seja concedida antecipação de tutela. ${ }^{28} \mathrm{~A}$ diferença residirá na maior amplitude dos requisitos. $\mathrm{Na}$ possessória de "força nova”, a turbação ou esbulho, comprovado sumariamente, basta para caracterizar o perigo de dano - impondo a concessão da medida urgente. Na ação de "posse velha”, há de se demonstrar algum fato adicional, que não permita aguardar-se o provimento final sem o risco de danos de difícil reparação.

Com o Art. 461-A tornou-se ainda possível que o juiz passe a cominar multa para o caso de descumprimento da ordem contida na medida provisional de "entrega de bens de uso pessoal do cônjuge e dos filhos" (Art. 888, III) inclusive quando esta for concedida antes do fim do processo.

Também aqui a ação de despejo pode vir a constituir exceção à diretriz geral ora afirmada, de modo que em princípio não lhe seriam subsidiariamente aplicáveis as regras em estudo. Vale o exposto acima: a lei criou para as relações de locação de imóveis um modelo típico de tutela destinado a proteger o locatário ao mesmo tempo em que confere instrumentos eficientes em prol do locador. A

vede, por todos, Ovídio B. da Silva, Procedimentos, n. 97, p. 202, n. 107, p. 227-228, n. 124, p. 263, n. 138, p. 283.

${ }^{28}$ Admitindo a antecipação de tutela em ação possessória fundada em "posse velha": $1 .{ }^{a}$ TACivSP, AI 707.295-1, v.u., rel. Juiz Álvares Lobo, j. 24.09.1996, em JTACSP-Lex 163/ 52; 2. TACivSP, AI 552.242, rel. Juiz Eros Piceli, j. 07.10.1998, em Bol. AASP 2.101, 5 a 11.04.1999, p. 7; 1. $\mathrm{a}$ TACivSP, AI 718.150-4, v.u., rel. Juiz Campo Mello, j. 14.11.1996, em $R T$ 740/329; TJSP, AI 209.684-4/9, v.u., rel. Des. Paulo Hungria, j. 26.06.2001, em RJ 286/99. 
generalizada extensão das regras dos Arts. 461 e 461-A à ação de despejo provavelmente afetaria esse delicado equilíbrio.

A título de comparação, pode ser citado o direito francês. Também lá, muito antes de a astreinte ser expressamente prevista em lei, já havia previsão especial destinada ao seu emprego nas ações de despejo. Posteriormente, a lei veio a prever a astreinte como medida geral, atribuindo-lhe um alcance e poder de coerção maiores do que os previstos na lei especial. Todavia, reputou-se inviável estender a nova norma geral para as ações de despejo, por razões de índole social. $^{29}$

Também os recentes projetos de reforma do processo italiano, que propõem o emprego da multa coercitiva nas condenações de qualquer espécie, excetuam as que incidam sobre relações de locação de imóveis urbanos. Nesse sentido, podem ser citados os projetos apresentados em 1996 e $2002 .{ }^{30}$

No direito brasileiro, é indicativa dessa possível postura a tendência de parte dos tribunais de nem mesmo admitir o emprego da regra geral da antecipação de tutela nas ações de despejo, em hipóteses distintas das lá tipificadas. ${ }^{31}$ Todavia, pede-se licença para ressaltar que o cogitado no presente texto não chega a esse ponto. Parece-nos que, em casos graves, a tutela antecipada pode ser concedida na ação de despejo, fora dos casos previstos no Art. 59, § 1. ${ }^{\circ}$, da Lei 8.245/91 como, aliás, já decidiu o STJ. ${ }^{32}$

\section{REFERÊNCIAS}

ARAGÃO, Egas D. Moniz de. Alterações no Código de Processo Civil: tutela antecipada, perícia. In: TEIXEIRA, Sálvio de Figueiredo (Org.). Reforma do Código de Processo Civil. São Paulo: Saraiva, 1996.

${ }^{29}$ Ver a respeito notas n. 83 e 98 de Procédures civiles d'exécution (PERROT; THÉRY, 2000, p. 98, 109).

${ }^{30}$ Quanto ao projeto de 1996, v., na Rivista di diritto processuale n. 4, de 1996, o texto do projeto e o relatório de apresentação, antecedidos de breve nota feita pelo presidente da Comissão encarregada da revisão, Giuseppe Tarzia (Per la revisione..., p. 945 e seguintes). Quanto ao projeto de 2002, conferir Allegato 1, da $2^{\text {a }}$ Comissão da Camara de Deputados italiana, de 24.07.20022, art. 21 - www.camera.it/_dati/leg14/lavori/ bollet/200207/0724/html/02//allegato.htm. Sobre ambos os projetos ver Tutela relativa aos deveres de fazer e de não fazer... (TALAMINI, 2003, p. 62-64, n. 2.1.5).

${ }^{31}$ Cf., p. ex., Conclusão 31 do Centro de Estudos do $2^{\circ}$ TACivSP.

${ }^{32}$ REsp 445.863-SP, rel. Min. José Arnaldo da Fonseca, julgado em 05.12.2002, Inf. STJ, n. $157,02-06.12 .2002$. 
. Comentários ao Código de Processo Civil. 7. ed. rev. e atual. Rio de Janeiro: Forense, 1992. v. 2.

BEDAQUE, José Roberto dos Santos. Tutela cautelar e tutela antecipada: tutelas sumárias e de urgência (tentativa de sistematização). São Paulo: Malheiros, 1998. BONDIOLI, Luis Guilherme Aidar. Tutela específica: inovações legislativas e questões polêmicas. In: COSTA, H. R. B. Ribeiro; RIBEIRO, J. H. H. Rezende; DINAMARCO, Pedro (Org.). A nova etapa da reforma do Código de Processo Civil. São Paulo: Saraiva, 2002.

BUENO, Cassio Scarpinella. Ensaio sobre o cumprimento das sentenças condenatórias. Revista de Processo, n. 113, 2004.

CHIOVENDA, Giuseppe. Instituições de direito processual civil. 2. ed. Trad. G. Menegale, da 2. ed. ital.). São Paulo: Saraiva, 1965. v. I.

CINTRA, Antonio Carlos de Araujo. Comentários ao CPC. 2. ed. Rio de Janeiro: Forense, 2003. v. 4.

DINAMARCO, Cândido R. A reforma da reforma. São Paulo: Malheiros, 2002.

GOMES, Orlando. Transformações gerais do direito das obrigações. 2. ed. São Paulo: RT, 1980.

GRECO FILHO, Vicente. Direito processual civil brasileiro. 11. ed. São Paulo: Saraiva, 1995. v. 1.

GUERRA, Marcelo Lima. Execução indireta. São Paulo: RT, 1998.

LIMA, Alcides de Mendonça. Comentários ao CPC. 6. ed. Rio de Janeiro: Forense, 1991. v. 6.

MAlACHINI, Edson Ribas. Comentários ao Código de Processo Civil. São Paulo: RT, 2001. v. 10.

MARINONI, L. Guilherme. A execução da tutela antecipatória de pagamento de soma sob pena de multa. Revista de Direito Processual Civil, 4, 1997.

MOREIRA, José Carlos Barbosa. A tutela específica do credor nas obrigações negativas. Temas de direito processual: segunda série. 2. ed. São Paulo: Saraiva, 1988.

. O novo processo civil brasileiro. 22. ed. Rio de Janeiro: Forense, 2002.

PASSOS, J. J. Calmon de. Comentários ao CPC. 6. ed. Rio de Janeiro: Forense, 1991.v. 3. 
PERROT, Roger; THÉRY, Philippe. Procédures civiles d'exécution. Paris: Dalloz, 2000.

RODRIGUES, Marcelo Abelha; JORGE, Flávio Cheim; DIDIER JR., Fredie. $A$ nova reforma processual. 2. ed. São Paulo: Saraiva, 2003.

RODRIGUES NETTO, Nelson. Notas sobre as tutelas mandamental e executiva lato sensu nas Leis 10.358/2001 e 10.444/2002. Revista de Processo, 110, 2003.

SILVA, Ovídio A. Baptista da. Procedimentos especiais (Exegese do CPC). Rio de Janeiro: Aide, 1989.

TALAMINI, Eduardo. Tutela relativa aos deveres de fazer e de não fazer - e sua extensão aos deveres de entrega de coisa (CPC, Arts. 461 e 461-A; CDC, Art. 84). 2. ed. São Paulo: RT, 2003.

. Tutelas mandamental e executiva lato sensu e a antecipação ex vi do

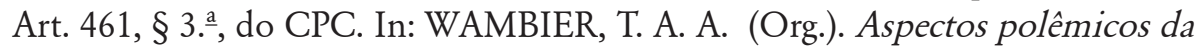
antecipação de tutela. São Paulo: RT, 1997.

Ainda sobre a prisão como "execução indireta": a criminalização da desobediência a ordens judiciais. In: SHIMURA, S.; WAMBIER, T. A. A. (Org.). Processo de execução São Paulo: RT, 2001.

. Prisão civil e penal e 'execução indireta' (a garantia do art. 5. da Constituição Federal. In: WAMBIER, T. A. A. (Org.). Processo de execução e assuntos afins. São Paulo: RT, 1998.

. Embargos do executado. Revista de Processo, 93, 1999.

TUCCI, José Rogério Cruz e. Lineamentos da nova reforma do CPC. 2. ed. São Paulo : RT, 2002.

VARELA, J. M. Antunes. Direito das obrigações: conceito, estrutura e funções da relação obrigacional, fontes das obrigações, modalidade das obrigações. Rio de Janeiro: Forense, 1977. v. I.

VIANA, JuvênScio Vasconcelos. Alterações nas execuções de obrigações de fazer, não fazer e entregar coisa. Revista Dialética de Direito Processual, 13, 2004.

WAMBIER, Luiz Rodrigues; ALMEIDA, Flávio C.; TALAMINI, Eduardo. Curso avançado de processo civil. 6. ed. São Paulo : RT, 2004. v. 2.

WAMBIER, Luiz Rodrigues; WAMBIER, Teresa Arruda Alvim. Breves comentários à segunda fase da reforma do Código de Processo Civil. 2. ed. São Paulo: RT, 2002. 